\author{
Asian Journal of Economic Modelling \\ $\operatorname{ISSN}(e): \quad 2312-3656$ \\ $\operatorname{ISSN}(p): \quad 2313-2884$ \\ DOI: $10.18488 /$ journal.8.2021.92.153.165 \\ Vol. 9, No. 2, 153-165. \\ (C) 2021 AESS Publications. All Rights Reserved. \\ URL: www.aessweb.com
}

\title{
MACROECONOMIC EFFECTS OF POLITICAL REGIME TYPE IN AFRICAN SUB-REGIONS
}

\section{Kabwe Omoyi Fanny}

\author{
Lecturer at the Faculty of Economics and Management Economic Analysis \\ and Policy Department CERME University of Dschang, Cameroon. \\ Email:fanny.kabrve@univ-dschang.org.Tel:(+2s7)697712933
}

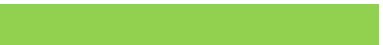

Article History

Received: 27 January 202 Revised: 5 March 2021

Accepted: 1 April 2021

Published: 29 April 2021

\section{Keywords \\ Economic growth \\ Democracy \\ Economic performance \\ African sub-regions \\ ECCAS \\ SADC \\ COMESA \\ CEPGL.}

\section{JEL Classification : O1; O4.}

\begin{abstract}
This paper is to empirically examine the effects of type of political regime on economic growth in a context of African Sub-Regions. Among the political determinants of the institutional environment, democracy as a Polity IV indicator is seen as contributing to stronger economic performance. We using a sample of panel data from 45 African countries over the period 1991 to 2019 , employs GMM difference regression. First, the results show that the type of political regime (especially democracy) improves economic performance (i.e. a one-point change in democracy increases economic performance by $63.4 \%$ in Central Africa, by $15.1 \%$ in Southern Africa, by $41.5 \%$ in East Africa). Second, the policy recommendations that flow from the findings are as follows: put education sector promotion issues at the heart of government strategies and therefore make it a priority; regional integration can serve as a "development" obligation that generates economic development and political stability.
\end{abstract}

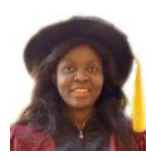

Contribution/Originality: This paper contributes to the various empirical works on the link between macroeconomics and democracy developed by Przeworski and Limongi (1993). The negative correlation between political regime and natural resource rents can be explained through economic performance, employment and education.

\section{INTRODUCTION}

Fundamentally, the relationship between income and democracy has its origins in modernisation theory ${ }^{1}$, which refers to a direct causal link between economic growth and democracy. According to this theory, economic growth generates 'a culture of democracy' (Lipset, 1959). Lipset (1959) thesis was developed in a rich society where

\footnotetext{
${ }^{1}$ Modernisation theory is a theory that argues that the differences that exist between the countries of the North and the South are mainly related to cultural problems. The dependency theory is opposed to this theory, in that it is a theory that argues that poverty, political instability and underdevelopment in the countries of the South is the consequence of historical processes put in place by the countries of the North resulting in the economic dependence of the countries of the South. Theorists of modernisation: Gino Germani, Alexander Gerschenkron, Lincoln Gordon, Talcott Parsons, Amartya Sen and Neil Smelser. All the theories fall within the field of social sciences (mainly sociology and economics). An empirical analysis developed in the work of Massil Keneck.

(http://www.academia.edu/17990225/La_Th\%C3\%A9orie_de_la_Modernisation_un_Examen_Empirique_en_Africa).
} 
relatively few citizens live in real poverty. There are two very different views on the relationship between the nature of the political regime and economic growth. Some argue that democracy disrupts production and increases uncertainty in the economy, reduces incentives for the accumulation of physical capital and reduces the rate of economic growth (Alesina \& Dani, 1994).

The causes of the collapse of economic growth go through several channels (according to studies by Wantchekon (1999)). In this paper we focus on: (i) the political regime and (ii) the natural resources. In the early 1990s, a number of African countries made the transition to democracy. Unfortunately, this first period of democratisation was marked by a decline in authoritarianism in a number of countries. In several of these countries, the presence of large natural resource endowments created the absence of democracy.

Many African countries are dependent on commodities as one of the main sources of government revenue and national wealth. Overall, the share of commodities in sub-Saharan Africa's exports increased from 57\% between 1990-1999 to 76\% between 2010-2019. The same situation has been observed in North Africa, however (World Bank, 2019).

Since 1991, Africa has experienced macroeconomic instability, but its mineral resource potential has led to the formation of several regional economic communities, including the Economic Community of Central African States (ECCAS), the Common Market for Southern Africa (COMESA), the Southern African Development Community (SADC), and many others that we will not consider in this study. Therefore, economic development and stability have direct implications between African regions. One of the main advantages of such a strategic location is that it offers many opportunities for trade, and for transforming countries into anchors for economic integration within the sub-region.

If we consider only the African economic regions, we can see that, regardless of democracy or dictatorship, the countries of ECCAS and CEPGL are subject to the effect of rent. This confirms the analysis of Ross (2001) who shows that the abundance of resources hinders democracy. The effect of democracy and mineral rents on economic performance is likely to depend on the regional context, as the increase in factors of production is certainly enhanced in a democratic environment.

Indeed, from the 1990s onwards, the African continent gradually opened up to democracy, but the structure of the appropriate economies was not yet the same as that of Western countries. The work of Azam, Berthélemy, and Stéphane (1996) has therefore focused on analysing the ways in which people can express themselves and influence economic policy in African countries. In particular, political violence (demonstrations, riots, coups d'état, etc.) may be their only means of action, with a very high human cost when the repression is severe.

These stylised facts raise many questions about the transmission channels of poor economic performance in African countries. Democracy has been widely studied in the economic literature (Wantchekon, 1999). There are two very different views on the relationship between the nature of the political regime and economic growth. Some argue that democracy disrupts production and increases uncertainty in the economy, reduces incentives for the accumulation of physical capital and reduces the rate of economic growth (Alesina \& Dani, 1994). Others argue that democracy involves substantial structural changes that undo political coalitions and induce painful readjustments in the power relations between different interest groups as it reduces social and political tensions [Alesina and Dani (1994); Alesina., Cohen, and Roubini (1992) and Barro (1999); Collier and Hoeffler (1998); Lujala (2005); Fearon and Laitin (2003) and Acemoglu and Robinson (2005)].

Several studies assess the effect of the nature of the political regime on economic growth. However, they are strongly focused on certain groups of countries. We observe some nuanced differences between the studies. For example, Wright, Frantz, and Geddes (2012) focus on regime (authoritarian and democratic), while Andersen and Aslaksen (2013) examine regime change only when the chief executive loses power with his political party. These results from panel studies of developing countries in general or sub-Saharan Africa in particular do not provide sufficient information on the state of the Sub regions. 
Therefore, as democracy and dictatorship are broad concepts, we will look at the case of a democracy in this literature review, consider works based on the country case. Several arguments, sometimes contradictory, are put forward to describe the impact of the political regime on growth.

Indeed, studies comparing the Far East with Latin America reveal that the political institutions of Asian countries make them growth-friendly (Przeworski \& Limongi, 1993). In this respect, non-democratic nations are more effective in addressing political dissent. This is because the authorities are less constrained by legal constraints on their coercive behaviour (Gupta et al. 1993 cited in Gupta, Madhavan, and Andrew (1998)).

Unlike previous empirical studies, this study adopts two strategies to investigate the causal effect of political regime on economic growth. The first strategy is to control for country-specific factors affecting both income and democracy by including country fixed and random effects (see Acemoglu and Robinson (2005)). As long as fixedeffects regressions are not a panacea for omitted variable bias. The main sources of potential bias in a policy regime regression on income are country-specific historical factors (political and economic development). When these omitted characteristics vary over time, the inclusion of fixed effects will not remove them. Consider, for example, the comparison between the DRC and South Africa. South Africa is both richer and more democratic. Therefore, a simple cross-country comparison would not suggest that there is a link between democracy and income.

The second strategy is to circumvent the endogeneity problem associated with this approach by including the generalised method of moments developed by Arellano and Bond (1991) and proposed by Holtz-Eakin, Newey, and Rosen (1988). When the hazards are correlated with one or more explanatory variables or when the classical assumptions of the linear model are violated, there is an endogeneity problem. The most general method to deal with such cases is the instrumental variables method.

The objective of this paper is to show how the type of political regime affects economic growth in Africa. As the type of political regime is likely to depend on the regional context. We consider African countries in their economic regions during the period 1991 to 2019. Our sample consists of 45 African countries. This offers interesting perspectives in terms of analysis, notably because this approach makes it possible to highlight the variability of situations that exist in the organisation of national and sub-regional systems. The question that arises is: Why do African countries not support democracy? The answer to this question confirms (Barro, 1999) hypothesis as follows: for a given standard of living, democracy tends to decline with a strong dependence on natural resources, which we will demonstrate in the next section.

Indeed, this paper contributes This paper contributes to the various empirical works on the link between macroeconomics and democracy developed by Przeworski and Limongi (1993). The negative correlation between political regime and natural resource rents can be explained through economic performance, employment and education. They argue that it is impossible to compare the impact of democracy and dictatorship, that dictatorships develop more easily when the economic situation is difficult. This choice makes it possible to observe and partly explain many cases of democracy and the consequences of the mineral wealth of the ECCAS for example. In view of the above, in addition to the introduction and conclusion, this paper is structured as follows: Section 1 presents a brief literature and analyses some empirical work on the country case. Section 2 presents the methodological approach. Section 3 presents the empirical results and economic interpretations.

\section{Section 1. Brief Literature and Analyses some Empirical Work on the Country Case}

Since the work of North (1993) a number of studies have emphasised the importance of political institutions for economic development. Good political institutions are expected to promote economic transactions mainly by reducing risks.

However, there are controversies about what good political institutions mean and the factors through which they impact on economic performance (Berthélemy, Kauffmann, Laurence, \& Wegner, 2002). Thus, among the questions that arise about 'good political institutions', one approach focuses on democracy as a synonym for a good 
institution. Although democracy has been widely studied in the economic literature, there have been few studies on its impact on economic performance in Africa in the last decade. We select works based on the cases of several countries in the world.

A first series of works has focused on the impact of political regime on economic growth. Przeworski and Limongi (1993) argue that democracy promotes growth. Studies comparing the Far East with Latin America reveal that the political institutions of Asian countries make them growth-friendly. In this respect, non-democratic nations are more effective in addressing political dissent. This is because the authorities are less constrained by legal constraints on their coercive behaviour (Gupta et al. 1993 cited in Gupta et al. (1998)).

In fact, Akagül (2003) examines the case of Turkey between 1950-2002 and confirms the findings that changes in political regimes lead to an increase in pressure for redistributive policies and slow down growth. The observation of political and economic data for Turkey over the period 1950-2002 tends to confirm that democracy improves political stability and development. In the case of 18 OECD economies, there is evidence of positive effects of electoral cycles on monetary and fiscal policy instruments and inflation (Alesina et al., 1992). several studies show that higher income leads a country to become more democratic. Panel studies confirm the Lipset/Aristotle hypothesis that a high standard of living of the population promotes democracy. Przeworski and Limongi (1993) and Barro. (1997) show that countries with a low level of economic development do not support democracy.

The question of how the nature of the political regime affects economic performance has recently received renewed attention. In particular, Alesina and Dani (1994) and Barro (1996) have identified the link between the stability of the political regime and development. From an empirical point of view, several studies assess the effect of the nature of the political regime on macroeconomic performance. However, they are strongly focused on certain groups of countries. We observe some nuanced differences between studies. For example, Wright et al. (2012) focus on regime (authoritarian and democracy) and find that democracy is conducive to growth, while Andersen and Aslaksen (2013) examine regime change only when the chief executive loses power with his or her political party and find that the length of time that some chief executives remain in power dampens economic performance.

Most authors prove that the abundance of resources is at the origin of bad African political systems with recurrent political crises. Ross (2001) for example, oil hinders democracy in poor countries more than in rich ones. Also, the author wonders about other resources such as minerals and others. He finds that the abundance of mineral resources hinders democracy. He gives the example of Angola, DRC, Peru and Chile.

Scholarship on the causes of democracy has sought to understand two empirical patterns: the strong correlative relationship between levels of material well-being and democracy (Acemoglu, Johnson, Robinson, \& Yared, 2009; Acemoglu, Simon, James, \& Pierre, 2008; Boix \& Susan, 2003; Lipset, 1959; Przeworski, Michael, Jose, \& Fernando, 2000) and the spatial and temporal clustering of democratization events (Ahlquist \& Erik, 2012; Brinks \& Michael, 2006; Gleditsch \& Ward, 2006; Houle, Mark, \& Jun, 2016; Huntington, 1993). Existing studies have treated these as distinct objects of inquiry, separately assessing the influence of domestic and international factors on the propensity to democratize (cited by Scott and Sergio (2020)).

\section{Section 2. Methodological Approach}

In this paper, we develop and estimate a model of Arellano and Bond (1991) proposed by Holtz-Eakin et al. (1988). Instead of using only the exogenous instruments listed above, the lagged levels of the endogenous variables in democracy and performance are also added. This makes the endogenous variables predetermined and, therefore, uncorrelated with the error term in the equations. To deal with the problem (fixed effects), the GMM difference uses first differences explain the correlation between economic growth and democracy and natural resources. 


\section{DATA}

For our main analysis, we obtain data from World Development Indicator (WDI) sources, each measured at the country-year. First, we obtain data on GDP \& Per Capita GDP from World Bank (2019). The data give estimates of annual GDP and GDP per capita between 1991-2019 for all of the African Sub regions in our sample of countries. Second, we obtain our dichotomous measure of Democracy from Policy IV ${ }^{2}$. This dataset provides an annual coding of democracy for every country in the world from 1990 to 2019.

\subsection{The Dependent Variables}

Economic growth rates are World Bank (2019). The democracy variable taking the value 1 for democratic regimes, o for authoritarian regimes. Data are from Polity $I V$ (source: author's construction based on data extracted from Policy $I V)$.

\subsection{Independent Variables}

We include economic variables such as mining and oil rents (World Bank, 2019); we cross-reference the rent variable with the ECCAS, SADC, COMESA and CEPGL dummy variables to demonstrate the rent effect in African countries. Thus, we distinguish the influence of these variables in the political regime and economic performance. The regional dummy variables are the African countries in the economic membership areas = a dummy ECCAS country, a dummy SADC country, a dummy COMESA country and a dummy CEPGL country except for the North and West African countries. Also, associated with the literacy rate and gross secondary school enrolment (Source: World Bank (2019)) and the other variables defined below: infant mortality, final consumption expenditure, population, GDP per person employed, government consumption expenditure (Source: World Bank (2019)).

\subsection{Empirical Strategy}

This study adopts two strategies to investigate the causal effect of political regime on economic growth. The first strategy is to control for country-specific factors affecting both income and democracy by including country fixed and random effects (see Acemoglu and Robinson (2005)). As long as fixed-effects regressions are not a panacea for omitted variable bias. The main sources of potential bias in a policy regime regression on income are countryspecific historical factors (political and economic development). When these omitted characteristics vary over time, the inclusion of fixed effects will not remove them. Consider, for example, the comparison between the DRC and South Africa. South Africa is both richer and more democratic. Therefore, a simple cross-country comparison would not suggest that there is a link between democracy and income.

The second strategy is to circumvent the endogeneity problem associated with this approach by including the generalised method of moments developed by Arellano and Bond (1991) and proposed by Holtz-Eakin et al. (1988). When the hazards are correlated with one or more explanatory variables or when the classical assumptions of the linear model are violated, there is an endogeneity problem. The most general method to deal with such cases is the instrumental variables method. We explicitly model the choice by democracy indicator Policy IV. This choice influences directly and indirectly through its effect on economic growth. Incumbents are uncertain about the relationship between democracy and growth, and they rely upon worldwide economic history to update their beliefs. For a panel of 45 African countries, we use data from 1991-2019. panel regressions typical of the approach taken in the existing empirical literature on democratization (Barro, 1999).

The success of two strategies models is rooted, first, in our estimates of the political implications of economic growth. In line with a sizable empirical literature in political economy, we find that democracies tend to reward incumbents for growth by keeping them in power (Alesina, Nouriel, \& Gerald, 1997; Brender \& Allan, 2008; Hibbs,

\footnotetext{
${ }^{2}$ http://www.systemicpeace.org/polity/polity4.htm.
} 
1977). In contrast, we find that natural resources tend to be stabilizing in autocracies in African Sub regions. Consequently, the following equation is estimated:

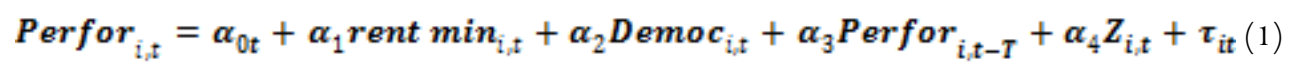

Where $\mathbf{i}$ is the country; $\mathrm{t}$ is the time;

$\mathbf{T}$ is the two-year lag.

Democ is the indicator for democracy or dictatorship.

Perfor is the indicator for economic growth rate.

$\mathbf{Z}$ is the vector of variables such as GDP per capita, inflation, life expectancy and education and

$\mathbf{V}, \mathbf{e}, \mathbf{t}$ are the error terms. the equations. To deal with the problem (fixed effects), the GMM difference uses first differences to transform the equation to:

$$
\Delta \operatorname{Perfor}_{i, t}=\alpha_{0 t}+\alpha_{1} \Delta \operatorname{rent} \min _{i, t}+\alpha_{2} \Delta \operatorname{Democ}_{i, t}+\alpha_{3} \Delta \operatorname{Perfor}_{i_{i} t-T}+\alpha_{4} Z_{i, t-T}+\Delta v_{i t}+\Delta e_{i t}(2)
$$

By transforming the variables into a difference, the country-specific effect is removed, as it does not vary with time. The equation we obtain: $\Delta \boldsymbol{\mu}_{i \boldsymbol{t}}=\Delta \boldsymbol{v}_{i t}+\Delta \boldsymbol{e}_{i \boldsymbol{t}}$. The lagged dependent variable is also instrumented with its previous levels. The Table 1 below provides information on the descriptive statistics from 1991 to 2019.

Table-1. Descriptive statistics.

\begin{tabular}{l|c|c|c|c|c}
\hline Variables & Observation & Average & Standard deviation & Minimum & Maximum \\
\hline Growth rate & 1083 & 4.264677 & 9.004294 & -62.07592 & 149.973 \\
\hline Democracy & 1075 & 0.6595349 & 0.4740862 & 0 & 1 \\
\hline Public consumption & 1001 & 2.629652 & 0.431467 & 0.7164347 & 4.488444 \\
\hline GDP/Person employed & 1100 & 8.854996 & 1.049203 & 6.708126 & 11.69589 \\
\hline GDP/H & 1047 & $2.75 \mathrm{e}+09$ & $1.97 \mathrm{e}+10$ & 82.67167 & $1.87 \mathrm{e}+11$ \\
\hline Public expenditure & 946 & 7.378123 & 7.987807 & 0.80521 & 44.33398 \\
\hline Mining rent & 968 & 1.405291 & 4.222596 & 0 & 54.16282 \\
\hline Inflation & 1054 & 60.02865 & 863.1039 & -31.56591 & 26762.02 \\
\hline Child mortality & 995 & 79.08633 & 30.56253 & 13.4 & 171.2 \\
\hline Total population & 984 & $1.73 \mathrm{e}+07$ & $2.24 \mathrm{e}+07$ & 118512 & $1.58 \mathrm{e}+08$ \\
\hline CEPGL & 1125 & 0.0666667 & 0.2495548 & 0 & 1 \\
\hline SADEC & 1125 & 0.2657778 & 0.4419429 & 0 & 1 \\
\hline COMESA & 1125 & 0.2666667 & 0.4424133 & 0 & 1 \\
\hline ECCAS & 1125 & 0.2888889 & 0.4534478 & 0 & 1 \\
\hline
\end{tabular}

Table 1 provides information on the descriptive statistics from 1991 to 2019. Each set of 1, 2, 3, 4, 5 columns corresponds to a different observation, average, standard deviation, minimum, maximum. The first row gives the

\footnotetext{
${ }^{3}$ Test: Ho: difference in coefficients not systematic

$\operatorname{chi} 2(8)=(\mathrm{b}-\mathrm{B})^{\prime}\left[\left(\mathrm{V}_{-} \mathrm{b}-\mathrm{V}_{-} \mathrm{B}\right)^{\wedge}(-1)\right](\mathrm{b}-\mathrm{B})=-615.64 \quad$ chi2 $<0==>$ model fitted on these data fails to meet the asymptotic assumptions of the Hausman test; see suest for a generalized test
} 
country-year observations each model correctly predicts. The reason is that, as democracy are quite rare (1075 total in-sample events), has a success rate of almost average $65 \%$.

\section{Section 3. Estimation Results and Discussion of the Results}

Table 2 results from a series of panel regressions typical of the approach taken in the existing empirical literature on democratization. Using GMM in difference models, we regress our democracy measure against GDP (see performance), and various controls. We exploit annual data World Development Indicator and, as in Barro (1999), 29-years panels. Table 2 provides information on the effects of political regime type on economic performance in Africa from 1991 to 2019.

Overall, these different analyses provide essential information for the theoretical and policy reviews presented in the economic policy recommendations. In this case, it is when considering the:

COMESA countries. We note that countries with poor democratic situations, which would be predicted on the basis of their income levels, generally have low levels of economic performance.

SADC, ECCAS and CEPGL show good but marginal levels of economic performance. The regressions also reveal that the government consumption expenditure and region variables enter the regressions with positive coefficients.

In column (3) of Table 2, COMESA countries, despite the fact that its countries suffer from conflicts, the level of democracy is improving (in the majority of countries, especially in the DRC) compared to countries in other regions. This result appears to be in total agreement with the work of Barro (1999) and Acemoglu and Robinson (2005). These authors confirm that the principle of democracy is based on the control of the power in place by the population of the country. One would therefore expect that in so-called democratic countries, whatever the levels of natural resource rents, the ruling elite cannot benefit from the rent more than the rest of the population, by hijacking and deteriorating the institutions. It is important to point out that economic performance in ECCAS countries only improves under conditions of stable democracy and good resource management.

However, most studies limit the analysis to the impact of political factors on economic performance. In contrast, Przeworski and Limongi (1993) suggest that the economic context has a significant influence on the development of institutions and could lead to democracy. Therefore, we have included mining rents and gone beyond them to show the influence of rents in democratic consolidation in African sub-regions. In the Central African states, mining rents tend to create situations of undemocracy.

Although our empirical results on natural resource dependency were not affected by the inclusion of the life expectancy variable, this variable is positive and statistically significant. Countries with higher levels of average life expectancy should be more democratic. Natural resources are no longer a determinant of political regimes when COMESA and SADC countries are taken into account. One possible explanation for this result is that the countries in these sub-regions are mostly well performing. As Yates says, "the idea is not to blame the lack of democracy and the presence of authoritarianism in Africa on the mere existence of oil, but to see whether African states really have democratic regimes rather than to show that these states conform to the rentier state model" (Yates, 1996). (i.e. a 10-point increase in democracy improves performance by 1.5 in SADC and 6.3 in ECCAS). Democracy implies rules and the opposition is a force that reduces the risk of arbitrary decisions.

Indeed, population growth is unfavourable for economic performance. Population growth reduces the quantity of capital per capita and therefore the product per capita. Population growth has a negative and significant effect on the growth of per capita product in accordance with Solow (1956). Dependence on natural resources is not conducive to the economic performance of SADC countries, since the economic structure in most cases is diversified, except for the DRC, which is extroverted and dependent on exports of its mineral resources. Only the ECCAS countries have a positive sign because mining revenues are a potential factor in economic growth in this African region. The coefficients associated with this variable are negative and significant for SADC and COMESA (in model 2, Table 2). That is, a 1-point increase in mining rents increases performance by 10.2 (Model 1, Table 2). 
Table-2. Effects of political regime type and economic growth.

\begin{tabular}{|c|c|c|c|c|c|c|c|c|}
\hline \multicolumn{9}{|c|}{$\begin{array}{l}\text { GMM in difference } \\
\text { Dependent variables: Economic growth rate, Political regime }\end{array}$} \\
\hline & $(1)$ & $(2)$ & (3) & $(4)$ & (5) & (6) & (7) & (8) \\
\hline \multirow[t]{2}{*}{$\begin{array}{l}\text { L. } \\
\text { Performance }\end{array}$} & $-0.527 * * *$ & $-0.211^{* * * *}$ & $-0.501^{* * *} *$ & $\begin{array}{c}- \\
0.201 * * *\end{array}$ & & & & \\
\hline & $(0.0960)$ & $(0.0582)$ & $(0.0839)$ & $(0.0576)$ & & & & \\
\hline \multirow[t]{2}{*}{$\begin{array}{l}\mathrm{L} \\
\text { Democracy }\end{array}$} & & & & & $0.656^{* * * *}$ & $0.477^{*} * *$ & $0.265 * * *$ & $0.572^{* *}$ \\
\hline & & & & & $(0.137)$ & $(0.185)$ & $(0.0658)$ & $(0.235)$ \\
\hline \multirow[t]{2}{*}{ Democracy } & $0.634 * * *$ & $0.151^{*}$ & 0.415 **** & $0.153 *$ & & & & \\
\hline & $(0.113)$ & $(0.0917)$ & $(0.0624)$ & $(0.0913)$ & & & & \\
\hline \multirow[t]{2}{*}{ Mining rent } & $0.102^{* * *}$ & $-0.0366^{* * *}$ & -0.0661 & -0.0275 & $-0.120 * *$ & -0.0516 & 0.00523 & $-0.448^{*}$ \\
\hline & $(0.0476)$ & $(0.0172)$ & $(0.0498)$ & $(0.0173)$ & (0.0513) & $(0.124)$ & $(0.0142)$ & $(0.256)$ \\
\hline \multirow[t]{2}{*}{ Performance } & & & & & $0.263^{*} *$ & $0.598 * * *$ & 0.0122 & -0.104 \\
\hline & & & & & $(0.102)$ & $(0.230)$ & (0.0483) & $(0.344)$ \\
\hline \multirow[t]{2}{*}{ Population } & $2.218^{* * * *}$ & 0.543 & $-1.578^{* * * *}$ & 0.383 & -0.592 & 1.805 & 0.464 & -0.820 \\
\hline & $(0.852)$ & $(0.439)$ & $(0.581)$ & $(0.405)$ & $(1.031)$ & $(1.411)$ & $(0.356)$ & $(4.689)$ \\
\hline \multirow[t]{2}{*}{ Child death } & $0.0202^{* * * *}$ & 0.00395 & $-0.00868^{* * *}$ & 0.00292 & $-0.0114^{*}$ & $0.0181^{* * *}$ & -0.00260 & 0.0290 \\
\hline & $(0.00571)$ & $(0.00446)$ & (0.00391) & $(0.00426)$ & $(0.00605)$ & (0.00901) & (0.00364) & $(0.0255)$ \\
\hline \multirow[t]{2}{*}{$\begin{array}{l}\text { Gross } \\
\text { registration }\end{array}$} & $-0.465^{* * * *}$ & 0.212 & $0.838^{* * * *}$ & $0.236^{*}$ & 0.295 & 0.0434 & -0.130 & 2.400 \\
\hline & $(0.177)$ & $(0.133)$ & $(0.229)$ & $(0.129)$ & $(0.187)$ & $(0.581)$ & $(0.110)$ & $(1.471)$ \\
\hline \multirow{2}{*}{$\begin{array}{l}\text { GDP/ } \\
\text { employment }\end{array}$} & $0.210^{* * *}$ & $0.132^{*}$ & $0.325 * * *$ & $0.133^{*}$ & 0.00770 & -0.116 & -0.0371 & 1.764 \\
\hline & $(0.0841)$ & $(0.0694)$ & $(0.0308)$ & $(0.0691)$ & $(0.0774)$ & $(0.107)$ & $(0.0583)$ & $(2.647)$ \\
\hline \multirow{2}{*}{$\begin{array}{l}\text { Final } \\
\text { cons. exp. }\end{array}$} & 0.206 & 0.0858 & -0.315 & 0.0979 & 0.238 & 0.957 & -0.0445 & $1.906 * *$ \\
\hline & $(0.254)$ & $(0.151)$ & $(0.281)$ & $(0.150)$ & $(0.305)$ & $(0.743)$ & $(0.124)$ & (0.883) \\
\hline \multirow{2}{*}{$\begin{array}{l}\text { Dep. cons. } \\
\text { apu }\end{array}$} & $-0.387^{*} * *$ & -0.105 & $0.440^{* * * * *}$ & -0.101 & 0.137 & -0.212 & $-0.275^{*} * *$ & $1.303^{* * *}$ \\
\hline & $(0.115)$ & $(0.110)$ & $(0.101)$ & (0.109) & $(0.127)$ & $(0.270)$ & $(0.0872)$ & $(0.516)$ \\
\hline \multirow[t]{2}{*}{$\begin{array}{l}\text { ECCAS } \\
* \text { Rent }\end{array}$} & -0.0113 & & & & $-0.0591^{*}$ & & & \\
\hline & $(0.0324)$ & & & & $(0.0341)$ & & & \\
\hline \multirow[t]{2}{*}{$\begin{array}{l}\text { CFDC } \\
\text { *Rent }\end{array}$} & & 0.0251 & & & & -0.0160 & & \\
\hline & & $(0.0310)$ & & & & $(0.0350)$ & & \\
\hline \multirow[t]{2}{*}{$\begin{array}{l}\text { COMESA } \\
\text { *Rent }\end{array}$} & & & 0.0222 & & & & 0.0183 & \\
\hline & & & $(0.0144)$ & & & & $(0.0252)$ & \\
\hline \multirow[t]{2}{*}{$\begin{array}{l}\text { CEPGL } \\
* \text { pension }\end{array}$} & & & & $\ldots \ldots$ & & & & 0.0507 \\
\hline & & & & & & & & $(0.0563)$ \\
\hline Comments & 53 & 347 & 43 & 347 & 53 & 43 & 347 & 17 \\
\hline $\begin{array}{l}\text { Number } \\
\text { of countries }\end{array}$ & 45 & 45 & 45 & 45 & 45 & 45 & 45 & 45 \\
\hline $\operatorname{AR}(1)$ & -1.89 & -5.41 & -1.06 & -5.44 & -3.45 & -3.17 & -5.07 & -2.80 \\
\hline $\operatorname{AR}(2)$ & -1.06 & -0.54 & -1.88 & -0.57 & 0.96 & -0.12 & 0.51 & -2.10 \\
\hline
\end{tabular}

Notes: Data on dummy regions were generated by ourselves using World Bank (2019) data, we consider 1 if countries are part of the zone and 0 otherwise. With * $\mathrm{p}$ $<0.10$. ${ }^{* *} \mathrm{p}<0,05 . * * * * \mathrm{p}<0.01$ and Hansen J or Sargan's Test: Ho: Non-correlation of instruments with residuals (test of validity of instruments); Arellano \& Bond's Test: Ho: Absence of an AR effect for residuals.

However, education has a negative effect on economic performance because in most Central African countries, the level of education is not considered a potential factor in economic performance because the government engages in several reforms aimed at protecting natural resources rather than addressing weaknesses in educational levels (i.e. a level of $46.6 \%$ reduces performance levels in Central Africa).

With regard to the effects on public consumption levels, final consumption and GDP per person employed. Resource endowment dependent countries spend more on public consumption than resource poor countries. With 
ECCAS, public consumption does not improve economic performance. This illustrates one of the mechanisms by which the peace and stability of ECCAS countries are seriously threatened. With employment, the coefficients enter with positive signs because employment is a contributing factor to economic growth.

We regressed all models using both random effects (GLS), fixed effects (OLS), and demonstrating the sensitivity of variables in the GMM model in difference. The empirical results are presented in Tables 3, 4 and 5 . These results are not in contradiction with the work done by Ross (2001). He showed empirically that the effects of policy variables such as political institutions contributed to improved economic performance. In many countries in the sub-regions, natural resources are not only an economic factor, but also a central element of domestic politics.

Indeed, controlling for country fixed effects, it appears that resource abundance explained by mining rent reduces economic performance. It is important to note that the macroeconomic effect on democracy and resource rents is extremely robust.

Table-3. Implication of democracy on economic performance in ECCAS and SADC from 1991 to 2019.

\begin{tabular}{|c|c|c|c|c|}
\hline & \multicolumn{2}{|c|}{ Estimate with EF } & \multicolumn{2}{|c|}{ Estimate with BR } \\
\hline & (1) & $(2)$ & (3) & $(4)$ \\
\hline \multirow[t]{2}{*}{ Democracy } & & $-0.210^{* * * *}$ & & $-0.489 * * *$ \\
\hline & & $(0.0755)$ & & $(0.155)$ \\
\hline \multirow[t]{2}{*}{ L-Performance } & $0.121^{*}$ & & $0.115^{*}$ & \\
\hline & $(0.0698)$ & & $(0.0675)$ & \\
\hline \multirow[t]{2}{*}{ GDP/employed persons } & $-0.153^{*} * *$ & & $-0.153^{*} * *$ & \\
\hline & $(0.0563)$ & $0.101 * * *$ & $(0.0527)$ & $0.202^{* * * *}$ \\
\hline \multirow[t]{2}{*}{ ECCAS*Rent } & $0.0387^{*}$ & $(0.0158)$ & $0.0336^{*}$ & $(0.0299)$ \\
\hline & $(0.0206)$ & $0.983^{* * *}$ & $(0.0189)$ & $0.975^{* * *}$ \\
\hline \multirow[t]{2}{*}{ SADC*Rent } & $0.0447^{* * *}$ & $(0.0159)$ & $0.0444^{* * * *}$ & $(0.0213)$ \\
\hline & $(0.0156)$ & & $(0.0150)$ & \\
\hline \multirow[t]{2}{*}{ Inflation } & & $-8.37 \mathrm{e}-07$ & & $1.87 \mathrm{e}-07$ \\
\hline & & $(7.46 \mathrm{e}-06)$ & & $(1.58 \mathrm{e}-05)$ \\
\hline \multirow[t]{2}{*}{ Life expectancy } & -0.0109 & $-0.0331^{* *}$ & -0.0112 & -0.00122 \\
\hline & $(0.0116)$ & $(0.0148)$ & $(0.0109)$ & $(0.0165)$ \\
\hline \multirow[t]{2}{*}{ Child mortality } & -0.00465 & -0.0153 & -0.00538 & -0.00172 \\
\hline & $(0.00530)$ & $(0.00957)$ & $(0.00481)$ & $(0.00362)$ \\
\hline \multirow[t]{2}{*}{ Literacy } & $-0.0120^{*}$ & $-0.0319 * * *$ & $-0.0113 * *$ & -0.00303 \\
\hline & $(0.00665)$ & $(0.00987)$ & $(0.00563)$ & $(0.00446)$ \\
\hline \multirow[t]{2}{*}{ Constant } & $3.601 * * *$ & $7.639^{* * * *}$ & $3.656^{* * *}$ & 2.021 \\
\hline & $(1.222)$ & $(2.095)$ & $(1.104)$ & $(1.296)$ \\
\hline Comments & 135 & 90 & 135 & 90 \\
\hline Number of countries & 10 & 45 & 10 & 45 \\
\hline $\mathrm{R} 2$ & 0.381 & 0.995 & - & - \\
\hline Chi2 & -0.69 & -615.64 & -0.69 & -615.64 \\
\hline
\end{tabular}

Notes: Data on dummy regions were generated by ourselves using data from the World Bank (2019). With * p <0.10. ** $\mathrm{p}$ $<0.05$. *** $\mathrm{p}<0.01$ and Hansen J or Sargan's Test: Ho: Non-correlation of instruments with residuals (test of instrument validity); Arellano \& Bond's Test: Ho: Absence of an AR effect for residuals.

In the ECCAS and SADC, the rent effect increase in real GDP has a negative effect on democracy. In ECCAS's case it can be argued that weaker economic performance has had a positive effect on political freedom (World Bank, 2019). This result is consistent with Collier and Hoeffler (2005) findings that in the presence of large rents from natural resources, autocracies outperform democracies.

The SADC, COMESA, ECCAS Sub regions depends on oil and minerals. Collier and Hoeffler (2005); Wantchekon (1999) found that in the absence of natural resource rents, a fully democratic polity outperforms a despotic autocracy by around 1.5 percentage points of growth per annum, but where natural resource rents are around $8 \%$ of GDP, in the absence of checks and balances, the growth advantage of democracy is eliminated.

As a check on the sensitivity of the findings using the Policy IV data on democracy, we reconsidered the findings using data from the comparative political economy database of political institutions published in the World 
Bank (2019) and downloadable from the World Bank website. This dataset has time series data for a range of political variables for the period 1991 to 2019.

Table-4. Effects of natural resources on economic growth.

\begin{tabular}{|c|c|c|c|c|c|c|}
\hline \multicolumn{7}{|c|}{$\begin{array}{l}\text { Estimated GMM in difference } \\
\text { Dependent variable: Economic growth rate }\end{array}$} \\
\hline \multirow[t]{2}{*}{ L. growth rate } & -0.0841 **** & $-0.0418^{*}$ & -0.0325 & 0.0115 & $0.0338 * * *$ & $0.0339 * * *$ \\
\hline & $(0.0261)$ & $(0.0241)$ & $(0.0226)$ & $(0.00738)$ & $(0.00568)$ & $(0.00495)$ \\
\hline \multirow[t]{2}{*}{ Civil violence } & $-0.994^{*}$ & $-3.735^{*}$ & $-2.973^{*}$ & $-0.588 * * *$ & $-1.399 * * *$ & $-2.017 * * *$ \\
\hline & $(0.568)$ & $(1.959)$ & $(1.564)$ & $(0.147)$ & $(0.509)$ & $(0.357)$ \\
\hline \multirow[t]{2}{*}{ Public expenditure } & & $0.797 * * *$ & $0.702^{* * * *}$ & $0.611 * * *$ & $0.589^{* * * *}$ & $0.623 * * *$ \\
\hline & & $(0.245)$ & $(0.185)$ & $(0.164)$ & $(0.126)$ & $(0.0949)$ \\
\hline \multirow[t]{2}{*}{ Mining rent } & & & -0.00613 & -0.0288 & $0.0848^{*}$ & $0.108 * * *$ \\
\hline & & & $(0.0812)$ & $(0.0492)$ & $(0.0499)$ & $(0.0350)$ \\
\hline \multirow[t]{2}{*}{ Inflation } & & & & $-0.000189^{* * *} *$ & $-0.000291 * * *$ & $-0.000316^{* * * *}$ \\
\hline & & & & $(3.08 \mathrm{e}-06)$ & $(2.55 \mathrm{e}-06)$ & $(1.86 \mathrm{e}-06)$ \\
\hline \multirow[t]{2}{*}{ Child mortality } & & & & & $0.167 * * *$ & $0.166^{* * * *}$ \\
\hline & & & & & $(0.0105)$ & $(0.0136)$ \\
\hline \multirow[t]{2}{*}{ Total population } & & & & & & $2.15 \mathrm{e}-08^{*}$ \\
\hline & & & & & & $(1.23 \mathrm{e}-08)$ \\
\hline \multirow[t]{2}{*}{ Constant } & $4.359^{* * * *}$ & -0.664 & -0.438 & -0.0175 & $-12.76^{* * * *}$ & $-13.45 * * *$ \\
\hline & $(0.263)$ & $(1.688)$ & $(1.259)$ & $(1.121)$ & $(1.563)$ & $(1.387)$ \\
\hline Comments & 994 & 844 & 742 & 728 & 712 & 711 \\
\hline Number of countries & 43 & 43 & 43 & 43 & 43 & 43 \\
\hline Ar 1p & 0.00795 & 0.0365 & 0.0418 & 0.0218 & 0.0251 & 0.0252 \\
\hline Ar2p & 0.200 & 0.264 & 0.323 & 0.458 & 0.496 & 0.495 \\
\hline Sargan & 271.0 & 167.0 & 143.0 & 141.1 & 177.1 & 178.4 \\
\hline Hansenp & 0.160 & 0.0616 & 0.137 & 0.150 & 0.169 & 0.337 \\
\hline
\end{tabular}

Note: With * $\mathrm{p}<0.10$. **** $\mathrm{p}<0.01$ and Hansen J or Sargan Test: Ho: No correlation of instruments with residuals (test of validity of instruments); Arellano \& Bond Test: Ho: No AR effect for residuals.

\section{CONCLUSION}

We propose and estimate a GMM in different in which democracy impact on economic growth. Our estimates indicate that growth is stabilizing for incumbents in democracies but destabilizing in autocracies of sample (19912019). In particular, our model jointly fixed and random effects (EF and RE) between income and democracy.

Overall, the recent resumption of growth in African countries as well as in several regional economic communities, notably the Economic Community of Central African States (ECCAS), the Common Market for Southern Africa (COMESA) and the Southern African Development Community (SADC), has remained largely "invisible" to the majority of the population. Accelerated growth with very low living standards continues to worsen. With the country's dependence on mineral and oil resources, the economies face structural difficulties, which have been exacerbated by political instability. These include economic diversity, availability and quality of infrastructure, unemployment (especially among youth), deteriorating social infrastructure and service delivery, and increasing income and wealth gaps (Economic Outlook, 2019). 
Table-5. Effects of policy regime type on economic growth

\begin{tabular}{|c|c|c|c|c|c|c|c|c|}
\hline \multicolumn{9}{|c|}{$\begin{array}{l}\text { Estimated GMM in difference } \\
\text { Dependent variable: Economic growth rate }\end{array}$} \\
\hline \multirow[t]{2}{*}{ L. growth rate } & -0.0325 & 0.0115 & $0.0338^{* * * *}$ & 0.0339 **** & -0.0841 1*** & $0.136^{* * * *}$ & $-0.0418^{*}$ & $0.0507 * * *$ \\
\hline & $(0.0226)$ & $(0.00738)$ & $(0.00568)$ & $(0.00495)$ & $(0.0261)$ & $(0.00792)$ & $(0.0241)$ & $(0.00838)$ \\
\hline \multirow[t]{2}{*}{ Democracy } & & & & & & & & $9.714^{* * * *}$ \\
\hline & & & & & & & & $(2.863)$ \\
\hline \multirow[t]{3}{*}{ Civil violence } & $-2.973^{*}$ & $-0.588^{* * * *}$ & $-1.399 * * *$ & $-2.017 * * *$ & $-0.994^{*}$ & 1.688 & $-3.735^{*}$ & -0.775 \\
\hline & $(1.564)$ & $(0.147)$ & (0.509) & $(0.357)$ & $(0.568)$ & $(1.116)$ & $(1.959)$ & $(1.562)$ \\
\hline & $0.702^{*} * *$ & $0.611^{* * * *}$ & $0.589^{* * *} *$ & $0.623^{* * *}$ & & $0.722^{* * *} *$ & $0.797 * * *$ & $0.371^{* *}$ \\
\hline \multirow[t]{2}{*}{ Public expenditure } & $(0.185)$ & $(0.164)$ & $(0.126)$ & $(0.0949)$ & & $(0.117)$ & $(0.245)$ & $(0.170)$ \\
\hline & -0.00613 & -0.0288 & $0.0848^{*}$ & $0.108^{* * *}$ & & $-0.540 * * *$ & & -0.0325 \\
\hline \multirow[t]{2}{*}{ Mining rent } & $(0.0812)$ & $(0.0492)$ & $(0.0499)$ & $(0.0350)$ & & $(0.169)$ & & $(0.207)$ \\
\hline & & $-0.000189^{* * * *}$ & $-0.000291 * * *$ & $-0.000316^{* * * *}$ & & $-0.000212^{* * * *}$ & & $\begin{array}{c}- \\
0.000243 * * *\end{array}$ \\
\hline \multirow[t]{2}{*}{ Inflation } & & $(3.08 \mathrm{e}-06)$ & $(2.55 \mathrm{e}-06)$ & $(1.86 \mathrm{e}-06)$ & & $(3.11 \mathrm{e}-06)$ & & $(3.64 \mathrm{e}-06)$ \\
\hline & & & $0.167^{* * * *}$ & $0.166^{* * * *}$ & & $-0.174 * * *$ & & -0.0117 \\
\hline \multirow[t]{2}{*}{ Child mortality } & & & $(0.0105)$ & $(0.0136)$ & & $(0.0218)$ & & $(0.0396)$ \\
\hline & & & & $2.15 \mathrm{e}-08^{*}$ & & $-9.19 \mathrm{e}-08^{*} * *$ & & $\begin{array}{l}-1.49 \mathrm{e}- \\
07 * * *\end{array}$ \\
\hline \multirow[t]{3}{*}{ Total population } & & & & $(1.23 \mathrm{e}-08)$ & & $(3.35 \mathrm{e}-08)$ & & $(4.74 \mathrm{e}-08)$ \\
\hline & & & & & & $-28.65 * *$ & & $-45.53 * * *$ \\
\hline & & & & & & $(13.53)$ & & $(12.61)$ \\
\hline \multirow[t]{2}{*}{ Dummy SADC } & & & & & & $53.54^{* * * *}$ & & 13.62 \\
\hline & & & & & & $(11.62)$ & & $(8.932)$ \\
\hline \multirow[t]{2}{*}{ Dummy CEPGL } & & & & & & $42.67^{* * * *}$ & & $42.15^{* * * *}$ \\
\hline & & & & & & $(12.65)$ & & $(10.63)$ \\
\hline \multirow[t]{2}{*}{ Dummy CEEAC } & & & & & & -8.658 & & -4.157 \\
\hline & & & & & & $(6.123)$ & & $(4.144)$ \\
\hline \multirow[t]{2}{*}{ Constant } & -0.438 & -0.0175 & $-12.76^{* * *}$ & $-13.45^{* * * *}$ & $4.359^{* * * *}$ & -6.754 & -0.664 & $-12.02^{*}$ \\
\hline & $(1.259)$ & $(1.121)$ & $(1.563)$ & $(1.387)$ & $(0.263)$ & $(6.079)$ & $(1.688)$ & $(6.567)$ \\
\hline Comments & 742 & 728 & 712 & 711 & 994 & 711 & 844 & 711 \\
\hline Number of countries & 43 & 43 & 43 & 43 & 43 & 43 & 43 & 43 \\
\hline Ar 1 & 0.0418 & 0.0218 & 0.0251 & 0.0252 & 0.00795 & 0.0274 & 0.0365 & $0.0507^{* * * *}$ \\
\hline Ar2 & 0.323 & 0.458 & 0.496 & 0.495 & 0.200 & 0.785 & 0.264 & $(0.00838)$ \\
\hline Sargent & 17 & 21 & 25 & 29 & 9 & 25 & 13 & $9.714^{* * * *}$ \\
\hline Hansen & 0.137 & 0.150 & 0.169 & 0.337 & 0.160 & 0.344 & 0.0616 & 0.484 \\
\hline
\end{tabular}


Therefore, we finally analyse the type of political regime as a consequence of performance in Africa. This is important because democracy is recognised as the best solution to the natural resource curse. In any case, the intensity of the observed relationship underlines the importance that we should now be concerned with the possible consequences of the nature of the political regime. Among the political determinants of the institutional environment, democracy is seen as contributing to stronger economic performance (i.e. a 10-point increase in democracy improves performance by $\mathbf{1 . 5}$ in SADC and by 6.3 in ECCAS).

The policy recommendations that flow from the findings are as follows: put education sector promotion issues at the heart of government strategies and therefore make it a priority; regional integration can serve as a "development" obligation that generates economic development and political stability.

Funding: This study received no specific financial support.

Competing Interests: The author declares that there are no conflicts of interests regarding the publication of this paper.

\section{REFERENCES}

Acemoglu, D., \& Robinson, J. A. (2005). The economic origins of democracy and dictatorship: Cambridge University Press.

Acemoglu, D., Johnson, S., Robinson, J. A., \& Yared, P. (2009). Reevaluating the modernization hypothesis. Journal of Monetary Economics, 56(8), 1043-1058. Available at: https://doi.org/10.1016/j.jmoneco.2009.10.002.

Acemoglu, D., Simon, J., James, A. R., \& Pierre, Y. (2008). Income and democracy. American Economic Review, 98(3), 808-842.

Ahlquist, J. S., \& Erik, W. (2012). Riding the wave: World trade and factor-based models of democratization. American Journal of Political Science, 56(2), 447-464. Available at: https://doi.org/10.1111/j.1540-5907.2011.00572.x.

Akagül, D. (2003). Democracy, political stability and development: An analysis of the Turkish case. Regulation Forum, 12. Alesina, A., \& Dani, R. (1994). Distributive Politics and economic growth. Quarterly Journal of Economics, 109(May), 465-490.

Alesina, A., Cohen, G., D., \& Roubini, N. (1992). Macroeconomic policy and elections in OECD democracies. Economics \& Politics, $4(1), 1-30$.

Alesina, A., Nouriel, R., \& Gerald, D. C. (1997). Political cycles and the macroeconomy. Cambridge, MA: MITPress.

Andersen, J., \& Aslaksen, S. (2013). Oil and political survival. Journal of Development Economics, 100(1), 89-106.

Arellano, M., \& Bond, S. (1991). Some tests of specification for panel data: Monte Carlo evidence and an application to employment equations. The Review of Economic Studies, 58(2), 277-297. Available at: https://doi.org/10.2307/2297968.

Azam, J., Berthélemy, J.-C., \& Stéphane, C. (1996). Recent developments in economic analysis. Economic Review, 47(3), 819-829.

Barro, R. J. (1996). Democracy and growth. Journal of Economic Growth, 1(1), 1-27.

Barro, R. J. (1999). Determinants of democracy. Journal of Political Economy, 107(S6), 158-183.

Barro, R. (1997). Determinants of economic growth: A cross-country empirical study: MIT Press.

Berthélemy, J., Kauffmann, C., Laurence, R. C., \& Wegner, L. (2002). Political instability, political regimes and economic performance in African countries. Université Paris I Panthéon Sorbonne, France and OECD Development Centre, 23.

Boix, C., \& Susan, C. S. (2003). Endogenous democratization. World Politics, 55(4), 517-549. Available at: https://doi.org/10.1353/wp.2003.0019.

Brender, A., \& Allan, D. (2008). How do budget deficits and economic growth affect reelection prospects? Evidence from a large panel of countries. American Economic Review, 98(5), 2203-2220. Available at: https://doi.org/10.1257/aer.98.5.2203.

Brinks, D., \& Michael, C. (2006). Diffusion is no illusion: Neighbor emulation in the third wave of democracy. Comparative Political Studies, 39(4), 463-489. Available at: https://doi.org/10.1177/0010414005276666.

Collier, P., \& Hoeffler, A. (1998). On economic causes of civil war. Oxford Economic Papers, 50(4), 563-573.

Collier, P., \& Hoeffler, A. (2005). Democracy and resource rents. Mimeo: University of Oxford.

Economic Outlook. (2019). African economic outlook (15th ed.).

Fearon, J., \& Laitin, D. (2003). Ethnicity, insurgency, and civil war. American Political Science Review, 97(1), 75-90.

Gleditsch, K. S., \& Ward, M. D. (2006). Diffusion and the international context of democratization. In International Organization. 
Gupta, D., Madhavan, M. C., \& Andrew, B. (1998). Democracy, economic growth and political instability: An integrated perspective. The Journal of Socio-Economics, 27(5), 587-611.

Hibbs, D. A. (1977). Political parties and macroeconomic policy. American Political Science Reviewe, 71(4), 1467-1487.

Holtz-Eakin, D., Newey, W., \& Rosen, H. S. (1988). Estimating vector autoregressions with panel data. Econometrica: Journal of the Econometric Society, 56(6), 1371-1395. Available at: https://doi.org/10.2307/1913103.

Houle, C., Mark, A. K., \& Jun, X. (2016). Diffusion or confusion? Clustered shocks and the conditional diffusion of democracy. International Organization, $70(4), 687-726$.

Huntington, S. P. (1993). The third wave: Democratization in the late twentieth century. Norman: University of Oklahoma Press.

Lipset, S. M. (1959). Some social requisites of democracy: Economic development and political legitimacy. American Political Science Revierw, 53(1), 69-105.

Lujala, P. (2005). Petroleum and civil war. Working Paper, Department of Economics, Norwegian University of Science and Technology.

North, D. (1993). The paradox of the West. Working Paper, Washington University St. Louis, Missouri.

Przeworski, A., \& Limongi, F. (1993). Democracy and development in South America, 1946-1988. Paper presented at the Annual Meeting of the American Political Science.

Przeworski, A., Michael, E. A., Jose, A. C., \& Fernando, L. (2000). Democracy and development: Political institutions and well-being in the world, 1950-1990. Cambridge: Cambridge University Press.

Ross, M. (2001). Does oil hinder democracy? World Politics, 53, 325-361.

Scott, F. A., \& Sergio, M. (2020). Learning about growth and democracy. American Political Science Reviewe, 114(4), $1195-1212$. Available at: https://doi.org/10.1017/So003055420000325.

Solow, R. (1956). The contribution to economic growth theory by Robert Solow : A major landmark and some of its undiscovered riches. The Quarterly Journal of Economics, 7O(1), 65-94.

Wantchekon, L. (1999). Why do resource abundant countries have authoritarian governments? Leitner Working Paper. Yale University.

World Bank. (2019). World development indicators 2019. Washington, DC: World Bank.

Wright, J., Frantz, E., \& Geddes, B. (2012). Oil and autocratic regime survival. Research in Progress, Preliminary Version Downloadable from: http://www.personal.psu.edu/jgw12/blogs/josephwright/rese.html.

Yates, D. A. (1996). The rentier state in Africa: Oil rent dependency and neocolonialism in the Republic of Gabon.

Views and opinions expressed in this article are the views and opinions of the author(s), Asian Journal of Economic Modelling shall not be responsible or answerable for any loss, damage or liability etc. caused in relation to/arising out of the use of the content. 